\title{
WORKER ADAPTATION AND EMPLOYER ACCOMMODATION FOLLOWING THE ONSET OF A HEALTH IMPAIRMENT
}

\author{
Mary C. Daly \\ John Bound
}

Working Paper No. 5169

\author{
NATIONAL BUREAU OF ECONOMIC RESEARCH \\ 1050 Massachusetts Avenue \\ Cambridge, MA 02138 \\ July 1995
}

This work was completed while Mary C. Daly was a National Institute on Aging post-doctoral fellow. Support for this research was provided by the National Institute on Aging and the Institute for Social Research at the University of Michigan. We thank Kenneth Couch, Sarah Laditka, Michael Schoenbaum, and three anonymous referees for their careful reading of earlier drafts of this paper. This paper is part of NBER's research programs in Aging and Labor Studies. Any opinions expressed are those of the authors and not those of the National Bureau of Economic Research.

(C) 1995 by Mary C. Daly and John Bound. All rights reserved. Short sections of text, not to exceed two paragraphs, may be quoted without explicit permission provided that full credit, including $(\odot)$ notice, is given to the source. 


\title{
WORKER ADAPTATION AND EMPLOYER \\ ACCOMMODATION FOLLOWING \\ THE ONSET OF A HEALTH IMPAIRMENT
}

\begin{abstract}
The responses of workers and their employers to the onset of work-limiting health impairments were investigated using data from the new Health and Retirement Survey. The results indicate that many workers who suffer from health limitations are directly accommodated by their employers, and that those who do not receive direct accommodation frequently adapt to their limitations by altering their job demands or by changing jobs. These findings point to the potential for adjustments on both sides of the market: by employers--in the form of job accommodation--and by employees--in the form of job change.
\end{abstract}

Mary C. Daly

Center for Policy Research

Syracuse University

426 Eggers Hall

Syracuse, NY 13203
John Bound

Department of Economics University of Michigan 1225 S. University Ann Arbor, MI 48106-2590 and NBER 
Maintaining individuals with health limitations in the labor force is one of the primary goals of the most recent United States policy concerning those with disabilities (West, 1991; Jones, 1991). The Americans with Disabilities Act of 1990 (ADA) requires employers with 15 employees or more to make reasonable accommodations for individuals with health problems unless such accommodation would cause an unreasonable hardship on business operations (Jones, 1991; ADA 102(b)(5)(A) and ADA 101(10)). One of the hopes underlying the ADA is that accommodation at the onset of a health impairment will delay job exit and subsequent movement onto the disability rolls.

Although the Americans with Disabilities Act was written into law in 1990, very little is known about the factors which influence an individual's ability to adapt to a health impairment and continue working, or about the nature and the range of accommodations and adjustments that individuals and their employers make to health limitations. What is known is that a sizable fraction of men and women nearing retirement age report health limitations on their capacity to work (Adams and Benson, 1992; Bound and Waidmann, 1992), and that while many of these individuals leave the workforce (U.S. Department of Commerce, 1973; Yelin, 1989, 
1992; Bound and Waidmann, 1992) a large fraction continue working in spite of their reported health impairments (McNeil, 1993; Burkhauser and Daly, 1993).

Despite the fact that a majority of individuals who experience a work-limiting health impairment remain in the labor market, little research has been done on the factors facilitating their continued work. Rather, most of the research on health and labor force activity has focussed on documenting the importance of health in explaining early labor force exit (Reno, 1971; Schwab, 1974; Sherman, 1985; Sammartino, 1987 reviews the literature) and on understanding other factors that contribute to early withdrawal (Parsons, 1980; Haveman and Wolfe, 1984, Bound, 1989; Bound and Waidmann, 1992; Yelin, 1992; Burkhauser et al., 1992). To some extent the absence of research on labor market activity following the onset of a health limitation can be attributed to a lack of the necessary data. Until recently the only surveys containing any information on such adjustments were the Surveys of the Disabled conducted in the 1960s and 1970s by the Census for the Social Security Administration. 
The newly available Health and Retirement Survey (HRS) permits further examination of this issue. A retrospective module in the first wave of the HRS contains detailed questions about changes that a cohort of workers and their employers made following the onset of a health limitation. These data provide the information necessary to report the prevalence of worker adaptation and employer accommodation among a cohort of men and women whose disabilities occurred prior to the passage of the Americans with Disabilities Act.

As noted, a large body of literature exists on the effects of health on early withdrawal from the labor market. In contrast, relatively little research has been done on the factors that facilitate continued work. This study focusses on this issue and examines the extent to which workers, through their own actions or those of their employer, adjust to their health limitations and continue working in the labor market. The sample is drawn based on self-reports about health conditions that limit the amount or type of work that can be performed. Analyses are performed separately for men and women to account for potential differences in the nature of the disabilities faced, and the opportunities for and rewards of continued work. 


\section{METHODS}

\section{Sample Development}

The analyses are based on data from the Health and Retirement Survey (HRS). The HRS contains contemporaneous data on health, employment, and income for men and women born between 1931 and 1941 . In addition, in the first wave of the HRS (1992) a special retrospective module of questions about disability was asked of respondents who reported that their health placed a current limit on their ability to perform paid work. The 1992 retrospective module is similar to the 1978 Survey of Disability and Work and includes questions about the onset of the present health limitation; the respondent's job characteristics before and after the impairment began; the respondent's employment behavior, disability benefit application and receipt, and spouse's work effort; as well as specific questions about employer accommodation following onset. Based on this retrospective information about the onset of disability and its impact on employment, pre- and post-impairment work histories for all individuals impaired at the time of the 1992 interview are created. Since the focus of the analysis is on the post-onset responses of working individuals and their 
5

employers, the sample is restricted to individuals who reported being impaired at the time of the interview, became impaired during their worklife, and were employed at its onset. After these restrictions are applied and spouses and partners outside of the appropriate age range are removed the analytic sample contains 1192 individuals -685 men and 507 women-with complete information.

\section{Key Variables}

Disability-An important concern in any study of the circumstances and behavior of people with disabilities is what definition of disability should be used to select the study population. The Americans with Disabilities Act defines disability as a physical or mental impairment that substantially limits one or more major life activities, a record of such an impairment, or being regarded as having such an impairment. This definition of disability is much broader than ones based on the receipt of disability-related transfers or on a purely objective set of medical criteria that do not incorporate information about the individual's environment, responsibilities, or human capital. Burkhauser and Daly (1995) suggest that this broader definition is useful when the research question focusses on 
individual responses to the onset of a health impairment and the factors that affect these responses. There are many methods of operationalizing a broader definition of disability (see LaPlante, 1991), but in most cases the selection depends largely on the availability of data.

In most nationally representative surveys of income and employment the data available on health are self-reported and couched in terms of work limitations. The problems inherent in these types of data are welldocumented (see Parsons, 1980; Bazzoli, 1985; Bound, 1991). Still, researchers have shown these measures to be highly correlated with more objective measures of health (see Bound, 1991 and Stern, 1989). In addition, self-reported work limitations are known to be highly correlated with reports on either chronic conditions or functional limitations (see, for example Burkhauser and Daly, 1995). Thus, while self-reported measures of work limitations contain potential biases, they do appear to adequately distinguish between those with and without a health impairment.

Employment Responses-HRS respondents with current health limitations who were employed at the onset of their impairment were asked whether, at that point in time, they stayed with their employer, changed 
employers or left the workforce altogether. Individuals who remained with their employer following onset are classified as having remained with employer; individuals who left their employer at onset and subsequently worked somewhere else are classified as having changed employers; and individuals who left their employer following onset and had not returned to work by the time of the interview are classified as permanently out of the labor force.

Job Demands-Respondents with current health limitations who were employed at the onset of their impairment were also asked to indicate the extent to which their job prior to onset required physical effort, lifting heavy loads, stooping, kneeling, or crouching, good eyesight, intense concentration, keeping a pace set by others, or skills in dealing with people. Those employed after the onset of their impairment were asked a similar set of questions about that job. Respondents were asked to report whether these descriptions were true of their jobs all or almost all of the time, most of the time, some of the time, or none or almost none of the time. Individuals who reported that they performed the task all, almost all, or most of the time were classified as having a job with that characteristic. 
In the multinomial logit analyses the detailed job demands are collapsed into four summary categories. The categories are designed to represent the four basic dimensions of job tasks that can be described with the data. These categories are: (1) job is physically demanding (i.e., requires physical effort, lifting heavy loads, or stooping, kneeling, or crouching; (2) job is mentally demanding (i.e., requires intense concentration or good eyesight; (3) job requires one to keep a pace set by others; (4) job requires interaction with people. A reduction in job demands is defined as a movement from performing a task all, almost all, or most of the time to performing the task only some of the time or none of the time.

Employer Accommodation-As with the job demand questions, the employer accommodation questions were asked of individuals who were employed at the onset of their impairment. Respondents were asked to report on whether they received accommodation from their employer at onset, first employer after onset, and their current employer. The first of these questions asked, "At the time your health started to limit your ability to work did your employer do anything special to help you out so that you 
could stay at work?" Those who changed employers following the onset of their health impairment were asked, "Did your new employer do anything special to make it easier for you to work at the job?" In addition, each person who reported that they were accommodated by their employer was asked to provide information on the type of assistance they received. Respondents were asked to report on eight specific types of accommodation, including: provide someone to help with job; shorten work day; allow schedule change; additional breaks and rest periods; special transportation; alter the job duties to something respondent could do; training for new skills; and special equipment. Information from these questions is used to describe the adaptations of workers following the onset of a health impairment.

\section{Analytic Strategy}

The responses of workers and their employers to the onset of worklimiting health impairments are examined in stages. For the first component of the analysis the sample is divided into those who remained with their employer at onset, those who changed employers, and those who left the labor force. Multinomial logit analysis is used to investigate the 
correlates of these three possible outcomes. This procedure is appropriate for estimating the influence of the covariates on the probabilities of being in one of the three choice groups. Under this method the error terms are assumed to be independently and identically distributed as a log Weibull distribution.

Previous researchers have found age, race, and education level to be important determinants of health related work loss (Haveman and Wolfe, 1990). Thus, the set of regressors includes the age at which the health condition first began to limit work, and dummy variables for African American, Hispanic, and level of schooling. Age at onset is the age the respondent recalls first being bothered by the health impairment that currently limits work. Education is a categorical variable distinguishing among individuals without a high school degree, high school graduates, individuals with some college, and college graduates. In the analysis the omitted category is individuals without a high school degree. To account for the employer side of the adaptation decision, information on employer size and whether the employee was covered by a union contract are also included as regressors. The employer size variable is the respondent's 
estimate of the number of workers the company employs in all locations. The analysis variable is the natural logarithm of employer size. Union status is the respondent's report that he/she is covered by a union contract.

Other factors not captured by these variables may also be important, such as income, occupation, and the severity of the impairment. Unfortunately, the HRS data contain very little information about income and occupation at the time of onset. The data do include each individual's reported health condition at onset. Eight health condition categories are used to account for differences in the types of impairments across the sample. The categories are: Cancers and Tumors; Musculoskeletal Conditions; Paralysis; Heart, Circulatory and Blood Conditions; Respiratory Ailments; Gastrointestinal, Metabolic, and Endocrine Conditions; Neurological and Sensory Conditions; Emotional and Psychological Conditions; and miscellaneous health problems including: infectious diseases, injuries and traumas, and reproductive health problems. The health condition at onset variables are included only as controls and are not discussed as part of the analysis. 
After the differences among those who remain with their employer, change employers, and stop working are examined, the sample is restricted to those who continued to work following the onset of their impairment. Within this sample, the adjustments that both employers and employees made following the onset of a health impairment are investigated by examining the prevalence of changes in job duties and employers, explicit employer accommodation, and their interactions.

In all of the analyses, results are reported separately for men and women. Previous research has shown that occupational differences and differences in job demands within the same occupation produce different effects of disability across men and women (Baldwin et al., 1994, Loprest et al., 1993). In addition, men are traditionally more attached to the labor force and may have more incentives to adapt or seek accommodation than women. These potential differences by gender suggest that separate analyses are appropriate.

As part of the sampling scheme the HRS oversamples by a factor of two African Americans, Hispanics, and residents of the state of Florida. The sample weights provided on the current release of the HRS are used to 
correct for this oversampling of particular populations. Using the sample weights the HRS should be roughly representative of the U.S. population 51 to 61 years old in 1992 . To account for the use of weighted data when performing the statistical tests (Clogg and Eliason, 1987; Rodgers, 1992), asymptotic results derived by Manski and Lerman (1977) are used. In fact, since the effective sample size (for the purposes of statistical tests, Kish, 1965 ) is only somewhat smaller than the actual sample size, doing so makes little difference to the reported results.

\section{RESULTS}

The first Table reports the proportion of individuals who were employed at the onset of their impairment and remained with their employer, changed employers, or left the work force and had not yet returned to the labor market by the survey date. Table 1 indicates that only about one-quarter of those who became impaired while employed exited the labor force and had not yet returned. A majority of individuals (just over one-half) continued with their employer at onset. The remaining individuals continued to work but changed employers. The patterns are similar among 
men and women, although a slightly larger proportion of women than men left the labor market.

Table 3 reports the results of a deeper look into the differences between those who remained with their employer, changed employers, or stopped working. Table 3 displays the coefficients and standard errors for a multinomial logit analysis in which remaining with the employer at onset is the baseline response. The coefficients can be interpreted as the fractional change in the odds of changing jobs or leaving the labor force relative to the odds of continuing on the current job associated with a oneunit change in the explanatory variable in question. The estimated effects of a change in each of the regressors on the probability of either changing employers or leaving the labor force are reported in brackets. The effects are evaluated at the mean of the dependent variable. Descriptive statistics for the regressors are reported in Table 2.

The results in Table 3 show that older workers are significantly more likely to remain with their initial employer than to change employers, but are also more likely to stop working after the onset of an impairment. Among men the coefficients on age at onset indicate that a one-year 
increase in the age at onset reduces the odds of changing employers relative to remaining with the initial employer by $(0.052)$, and increases the odds of leaving the labor force relative to remaining with their employer at onset by (0.033). Thus, the effect of a one-year increase in age at onset is to decrease the probability of changing employers by 0.01 percentage points, and to increase the probability of leaving the labor market by 0.009 percentage points.

In general, age at onset has a similar effect on the patterns of response among women. However, in some cases the magnitude of the responses is greater. A one-year increase in age at onset among women reduces the odds of changing employers by $(0.087)$ and increases the odds of stopping work by (0.031). This implies that a one-year increase in age at onset decreases the probability of changing employers by 0.02 percentage points, but increases the probability of leaving the labor force by 0.12 percentage points, a magnitude almost 15 times as large as the response among men.

Men and women with at least a high school or college degree are less likely to stop working than are high school dropouts; having a high 
school education decreases the probability of leaving the labor force by about 0.18 percentage points. Race and ethnicity have no significant effect on the employment outcomes of men following the onset of an impairment, but do seem to influence women. African American females are less likely to change employers and more likely to leave the labor force than are their white counterparts. Being an African American women reduces the probability of changing employers by .195 percentage points but increases the probability of leaving the labor force by .186 percentage points. Job characteristics appear to have no influence on the probability that individuals will leave the labor force or change employers.

Among characteristics of the employment relationship, characteristics of the employer are the most powerful predictors of a worker's response to a health problem. Both men and women employed in large firms are significantly more likely to remain with their employer at onset than they are to leave the labor force or change employers. In addition, women covered by union contracts are significantly less likely to leave their employer at onset. Being a union member decreases the probability that the 
mean woman will leave the labor force by 0.04 percentage points. Union status has no significant impact on the responses of men.

In Table 4 the sample is reduced to only those individuals who worked at some point after the onset of their health impairment. Table 4 focusses on job duties before and after the onset of an impairment. The results are reported separately for workers who remained with their employer at onset and for workers who changed jobs. The proportions represent the fraction of workers who performed the listed tasks all, almost all, or most of the time, before and after the onset of their impairment. The net proportion reflects the change in the proportion with a particular job demand following the onset of an impairment. The results indicate that with few exceptions a significant proportion of individuals working at jobs with continual physical and/or mental demands reduced these demands following the onset of a health impairment. The net changes in physical job demands and working at a fixed pace were higher for workers who changed employers than for workers who remained with their employer after onset. However, these differences were only significant for women. Overall, men and women who changed jobs were significantly more likely to report a 
reduction in job demands along some dimension than men and women who remained with their employer following the onset of a health condition (odds ratios of 1.58 for men and 2.29 for women).

Using the sample described in Table 4, Table 5 looks more directly at explicit employer efforts to retain workers with health limitations. Table 5 describes the prevalence of reported employer accommodation and compares the experiences of workers who remained with their employer with those of workers who changed employers. Significantly more men and women who remained with their employer after the onset of their health condition reported receiving accommodation from their employer. About one-third of the men and women who remained with their employer indicated that they were explicitly accommodated. A significantly smaller fraction (14.1 percent) of men who changed employers reported explicit accommodation on the part of their employer. The situation for women was slightly different. Nearly one-quarter of the women with an employer other than their employer at onset reported that they were accommodated.

Among workers who remained with their employer, accommodation was most commonly provided in the form of an alteration in job duties, 
assistance with the job, a change in schedule or a shorter work day, and more breaks. There were no clear patterns among workers who were accommodated by a new employer. The least common type of accommodation for both groups was special transportation.

The results from Tables 4 and 5 suggest that individuals who change employers are significantly more likely to change the demands of their job than those who stay, but that explicit employer accommodation is more common for workers who remain than for those who move to a new employer. However, changes in job demands and employer accommodation are not mutually exclusive alternatives. In fact, men and women who were accommodated by their employer at onset were more than three times as likely to report a job change than were individuals who remained with their employer at onset but did not report being accommodated. Although this does not account for differences in needs among those who were and were not accommodated the results do suggest that in some cases job demands and reported accommodation go hand in hand. 


\section{DISCUSSION}

As is well recognized (Nagi, 1965; Pope and Tarlov, 1991), (work) disabilities often reflect mismatches between an individual's capacities and the physical or mental demands of a job. Thus, many individuals with health limitations on their capacities to work may be able to continue in the labor market by overcoming this mismatch. This paper has documented the kinds of adjustments that a cohort of workers and their employers made following the onset of work-limiting health impairments before explicit and comprehensive government protection of people with disabilities was in place. The findings indicate that among those employed at the onset of their health limitation, a majority continued to work and that, of these, a majority continued to work for the same employer. In addition, more than one-third of those who continued to work for the same employer mentioned specific ways in which their employer had accommodated them.

Not surprisingly, age and education play an important role in determining the employment outcomes for workers following the onset of a health impairment. Older workers are more likely to stay with their original employer if they continue to work, but are less likely to continue 
in the labor market. This result is open to a variety of interpretations. Older workers who leave their employer may be more severely impaired, may not have a marketable set of skills to transfer to a job more suited to their capacities, or may see the costs of unemployment until retirement as less than the costs of retraining or an extensive job search. Unfortunately, the retrospective module of the HRS does not contain sufficient information to determine why older individuals leave the labor market.

Education has little effect on the likelihood that workers will change employers, but workers with at least a high school education were less likely to stop working after the onset of a health impairment. Like age, the lack of a high school education may make it more difficult for workers with impairments to find alternative employment that matches their capacities. Baldwin and Johnson (1994) argue that these individuals-those with less than average work experience or fewer skills-face discrimination associated with their impairment apart from any productivity losses. Among women who become impaired, being African American reduces the likelihood of continued labor market work. Like older workers African American women are less likely to change employers and more likely to 
stop working than other women. Again, the retrospective data provide no information about why these individuals stopped working.

Although other researchers have found differences in the effects of disability on men and women, few of the results presented here indicate gender specific behavior. Men and women who continue to work following the onset of a health impairment appear to make similar adaptations and receive corresponding levels of employer accommodation. One result that does indicate potential gender differences is in the decision to leave the labor market or continue working following onset. The findings indicate that women are more likely to leave the labor market after the onset of an impairment than are men. Part of this difference could be explained by the relative importance of male and female earnings in household budgets. In a majority of households, particularly in this age cohort, men remain the primary earners. Thus, labor market withdrawal may be more of an option for women than it is for equally disabled men.

While the retrospective data provide little information about the causes of the differences reported here, they do give an impression of the groups at risk for leaving the labor market or changing employers following 
the onset of a health impairment. From these descriptive results one can speculate about why certain groups are more successful than other in either remaining with their employer after onset or changing employers but remaining in the labor market. Older workers and workers with less than a high school education may be insufficiently skilled to gain employment in an enterprise more suited to their post-onset capacities. Presumably, younger workers and workers with more education would have a larger set of opportunities and might find it more beneficial to retrain in order to find new employment. To the extent that African American women face labor market discrimination these women may find their opportunities for job changing to be more limited. In general, these results indicate that traditional factors associated with differential outcomes in the labor market also account for differential outcomes in the post-onset employment responses of people with disabilities.

Among those workers who continued to work following the onset of an impairment the findings indicate that many of those who remained with their pre-onset employer experienced a combination of reductions in their job demands and explicit employer assistance. For those who changed jobs, 
adaptation occurred more often through changes in job demands than through employer accommodation. The finding that a significant fraction of employers made accommodations for their employees prior to the passage of the ADA is consistent with research done on the 1972 and 1978 Surveys of the Disabled (Schechter, 1981; Lando, Cutler, and Gamber, 1982; Burkhauser et al., 1992) which indicate that nearly one-third of those who experience a disability report some form of employer accommodation. These findings support recent anecdotal evidence that suggests that employer accommodation following disability is not uncommon (Chirikos, 1991) and may contribute to a worker's ability to remain in the labor market.

The results presented here provide population-based descriptive information to support the anecdotal evidence that employers often accommodate workers who suffer health impairments and that among workers who are not explicitly accommodated changes in employers and job duties often occur. However, this does not imply that everyone who experiences a health impairment will be able to continue working. A large part of this determination will have to do with the severity of the limitation 
(McNeil, 1993). This can be true either because severity affects an individual's capacity to continue working or because it affects an employer's willingness and/or ability to make accommodations. Employers may be more likely to accommodate milder impairments while accommodation may be more essential for those with more severe limitations. Although the retrospective portion of the HRS data do not permit an investigation of the relationship between severity and accommodation or employee adaptation, other research suggests that some employers are willing to accommodate individuals with impairments severe enough to qualify them for disability benefits (Hennessey and Muller, 1994). This paper highlights the possibility of adaptations to the onset of a disability on both sides of the labor market: by employers (in the form of job accommodation) and by employees (in the form of a reduction in job demands through changes in jobs and/or employers). In addition, the findings suggest that employers, particularly large employers, play an important role in protecting impaired workers from work losses associated with the onset of a health impairment. A natural next step to understanding the potential impact of the ADA is to ask whether the changes in job duties 
and employer accommodations lengthen the active working life of impaired workers. It will also be important to investigate which workers receive accommodation and under what circumstances. These are the types of questions that need to be answered before the potential effectiveness of laws such as the ADA can be evaluated. 


\section{References}

Adams, Patricia F. and Benson, Veronica. 1992. "Current Estimates from the National Health Interview Survey, 1991." National Center for Health Statistics. Vital Health Statistics 10(184).

Baldwin, Marjorie L. and William G. Johnson. 1994. "Labor Market Discrimination Against Men with Disabilities." Journal of Human Resources 29 (1): 1-19.

Baldwin, Marjorie L., Lester A. Zeager, and Paul R. Flacco. 1994. "Gender Differences in Wage Losses from Impairments," Journal of Human Resources 29 (3): 865-887.

Bazzoli, Gloria J. 1985. "The Early Retirement Decision: New Empirical Evidence on the Influence of Health." Journal of Human Resources 20 (2): 214-234.

Bound, John and Timothy Waidmann. 1992. "Disability Transfers and the Labor Force Attachment of Older Men: Evidence from the Historical Record." Quarterly Journal of Economics 107 (November): 1395-1419.

Bound, John. 1991. "Self-Reported versus Objective Measures of Health in Retirement Models." Journal of Human Resources 26 (1): 106-138.

Bound, John. 1989. "The Health and Earnings of Rejected Disability Insurance Applicants." American Economic Review 79 (June):482-503.

Burkhauser, Richard V., and Mary C. Daly. 1995. "Employment and Economic Well-Being Following the Onset of a Disability: The Role for Public Policy," presented at the Disability, Work, and Cash Benefits Workshop, Santa Monica, CA, December 1994. 
Burkhauser, Richard V., J. S. Butler, Yang Woo Kim, and George A. Slotsve. 1992. "Modeling Application for Disability Insurance as a Retirement Decision: A Hazard Model Approach Using Choice-Based Sampling." Metropolitan Studies Program Policy Series Paper No. 3. ISSN \#1061-1843. Syracuse, New York: The Maxwell School of Citizenship and Public Affairs.

Chirikos, Thomas N. 1991. "The Economics of Employment." In Jane West (ed.) The Americans with Disabilities Act: From Policy to Practice. The Milbank Memorial Fund.

Clogg, Clifford D., and Eliason, Scott R. 1987. "Some Common Problems in Log-Linear Analysis," Sociological Methods and Research 16:844.

Haveman, Robert H. and Barbara L. Wolfe. 1984. "Disability Transfers and Early Retirement: A Causal Relationship." Journal of Public Economics 22 (June):47-66.

Haveman, Robert H. and Barbara L. Wolfe. 1990. "The Economic WellBeing of the Disabled,1962-1984." Journal of Human Resources, 25(1): 32-55.

Hennessey, John C. and L. Scott Muller. 1994. "Work Efforts of DisabledWorker Beneficiaries: Preliminary Findings From the New Beneficiary Followup Survey." Social Security Bulletin, 57 (3): 4251 .

Jones, Nancy L. 1991. "Essential Requirements of the Act: A Short History and Overview." In Jane West (ed.), The Americans with Disabilities Act: From Policy to Practice. The Milbank Memorial Fund.

Kish, Leslie. 1965. Survey Sampling, New York: Wiley. 
Lando, M., R.Cutler, and E. Gamber. 1982. 1978 Survey of Disability and Work: Data Book Preliminary. Washington, D.C.: GPO.

LaPlante, Mitchell P. 1991. "The Demographics of Disability." In Jane West (ed.) The Americans with Disabilities Act: From Policy to Practice. The Milbank Memorial Fund.

Loprest, Pamela, Kalman Rupp, and Steven Sandell. 1993. "Women's Disabilities, Employment, and Social Security Disability." Journal of Human Resources (forthcoming)

Manski, Charles F. and Steven R. Lerman. 1977. "the Estimation of Choice Probabilities From Choice Based Samples." Econometrica 45:1977-1988.

McNeil, John M. 1993. "Americans with Disabilities 1991-92," Current Population Reports, Household Economic Studies P70-33. Washington, D.C.: U.S. Department of Commerce, Bureau of the Census.

Nagi, Sadd Z. 1965. "Some Conceptual Issues in Disability among Adults in the United States." Milbank Memorial Fund Quarterly $54: 439-467$.

Parsons, Donald O. 1980. "The Decline of Male Labor Force Participation." Journal of Political Economy 88 (February):117-34.

Pope, Andrew M. and Alvin R. Tarlov (Eds). 1991. Disability in America: Toward a National Agenda for Prevention. Division of Health Promotion and Disease Prevention, Institute of Medicine. Washington, D.C.: National Academy Press.

Reno, Virginia. 1971. "Why Men Stop Working at or before Age Sixty-five." Social Security Bulletin 34 (June):3-16. 
Rodgers, Willard L. 1992. "Estimating Population Parameters From Weighted Sample Data," University of Michigan Mimeo.

Sammartino, Frank J. 1987. "The Effect of Health on Retirement." Social Security Bulletin 50 (February):31- 47.

Schechter, Evan S. 1981. "Employment and Work Adjustments of the Disabled." Disability Survey 72: Disabled and Nondisabled Adults. Department of Health and Human Services Social Security Administration, Office of Policy, Office of Research and Statistics Research Report No. 56, Chapter 14.

Schwab, Karen. 1974. "Early Labor Force Withdrawal of Men: Participants and Non-Participants Aged 58-63." Social Security Bulletin 37 (August):24-38.

Sherman, Sally R. 1985. "Reported Reasons Retired Workers Left Their Last Job: Findings from the New Beneficiary Survey." Social Security Bulletin 48 (March):22-30.

Stern, Steven. 1989. "Measuring the Effect of Disability on Labor Force Participation." Journal of Human Resources. 24 (3):361-95.

U.S. Department of Commerce Publication. 1973. "Persons with Work Disability." 1970 Census of Population.

West, Jane. 1991. "The Social and Policy Context of the Act." In Jane West (ed.), The Americans with Disabilities Act: From Policy to Practice. The Milbank Memorial Fund.

Yelin, Edward H. 1989. "Displaced Concern: The Social Context of the Work Disability Problem." Milbank Memorial Fund Quarterly 67(supp. 2, part 1):114-166.

Yelin, Edward H. 1992. Disability and the Displaced Worker. New Brunswick, New Jersey: Rutgers University Press. 
Table 1. Employment Responses to the Onset of a Health Impairment

Men and Women with a Current Health Impairment that Began During Worklife

\begin{tabular}{lccc}
\hline & $\begin{array}{c}\text { Total } \\
(\mathbf{N = 1 1 9 2})\end{array}$ & $\begin{array}{c}\text { Men } \\
(\mathbf{N = 6 8 5})\end{array}$ & $\begin{array}{c}\text { Women } \\
(\mathbf{N = 5 0 7 )}\end{array}$ \\
\hline $\begin{array}{l}\text { Proportion Who Remained with } \\
\text { Their Employer Following Onset }\end{array}$ & 50.5 & 51.4 & 49.1 \\
$\begin{array}{l}\text { Proportion Who Changed Employers } \\
\text { Following Onset }\end{array}$ & 22.9 & 24.1 & 21.4 \\
$\begin{array}{l}\text { Proportion Who Stopped Working } \\
\text { and Never Worked Again }\end{array}$ & 26.6 & 24.5 & 29.5 \\
\hline
\end{tabular}


Table 2. Descriptive Statistics for Multinomial Logit Analysis

\begin{tabular}{|c|c|c|c|c|}
\hline \multirow[b]{2}{*}{ Regressors } & \multicolumn{2}{|c|}{ Men } & \multicolumn{2}{|c|}{ Women } \\
\hline & Mean & Std & Mean & Std \\
\hline \multicolumn{5}{|l|}{ Demographic Variables } \\
\hline Age at Onset & 46.38 & 9.03 & 47.68 & 7.58 \\
\hline Black & 0.13 & 0.34 & 0.19 & 0.39 \\
\hline Hispanic & 0.07 & 0.25 & 0.06 & 0.23 \\
\hline High School Graduate & 0.69 & 0.46 & 0.69 & 0.46 \\
\hline Some College & 0.13 & 0.34 & 0.13 & 0.34 \\
\hline College Graduate & 0.13 & 0.33 & 0.08 & 0.27 \\
\hline \multicolumn{5}{|l|}{ Employer Characteristics } \\
\hline Employer Size & 4.59 & 2.69 & 4.78 & 2.53 \\
\hline Union Status & 0.30 & 0.46 & 0.20 & 0.40 \\
\hline \multicolumn{5}{|l|}{ Job Characteristics } \\
\hline Physically Demanding & 0.71 & 0.45 & 0.68 & 0.47 \\
\hline Pace Set By Others & 0.64 & 0.48 & 0.70 & 0.46 \\
\hline Mentally Demanding & 0.95 & 0.21 & 0.94 & 0.23 \\
\hline Deal with People & 0.75 & 0.43 & 0.81 & 0.39 \\
\hline \multicolumn{5}{|l|}{ Primary Health Condition } \\
\hline Cancers and Tumors & 0.01 & 0.11 & 0.03 & 0.18 \\
\hline Musculoskeletal & 0.45 & 0.50 & 0.56 & 0.50 \\
\hline Paralysis & 0.02 & 0.13 & 0.02 & 0.11 \\
\hline Heart, Circulatory, Blood & 0.24 & 0.43 & 0.12 & 0.32 \\
\hline Respiratory & 0.08 & 0.28 & 0.08 & 0.27 \\
\hline $\begin{array}{l}\text { Gastrointestinal, Metabolic, } \\
\text { Endocrine }\end{array}$ & 0.05 & 0.22 & 0.07 & 0.25 \\
\hline Neurological and Sensory & 0.03 & 0.18 & 0.03 & 0.18 \\
\hline Emotional and Psychological & 0.02 & 0.13 & 0.02 & 0.14 \\
\hline Miscellaneous Health Problems & 0.10 & 0.31 & 0.07 & 0.29 \\
\hline
\end{tabular}


Table 3. Multinomial Logit Analysis of Employment Responses to the Onset of a Health Impairment, By Gender

\begin{tabular}{|c|c|c|c|c|}
\hline \multirow[b]{2}{*}{ Regressors } & \multicolumn{2}{|c|}{ Men } & \multicolumn{2}{|c|}{ Women } \\
\hline & Changed Employers & Stopped Working & Changed Employers & Stopped Working \\
\hline & $\begin{array}{c}\text { Coefficient } \\
\text { Standard Error () } \\
\text { Derivative Evaluated } \\
\text { at } \mathrm{Y}\{\}\end{array}$ & $\begin{array}{c}\text { Coefficient } \\
\text { Standard Error () } \\
\text { Derivative } \\
\text { Evaluated at } \mathrm{Y}\{\}\end{array}$ & $\begin{array}{c}\text { Coefficient } \\
\text { Standard Error () } \\
\text { Derivative Evaluated } \\
\text { at } Y\{\}\end{array}$ & $\begin{array}{c}\text { Coefficient } \\
\text { Standard Error }() \\
\text { Derivative } \\
\text { Evaluated at } \mathrm{Y}\{\}\end{array}$ \\
\hline \multicolumn{5}{|l|}{$\begin{array}{l}\text { Demographic } \\
\text { Variables }\end{array}$} \\
\hline Age at Onset & $\begin{array}{c}-0.052^{* *} \\
(0.013) \\
\{-0.011\}\end{array}$ & $\begin{array}{c}0.033^{*} \\
(0.014) \\
\{0.009\}\end{array}$ & $\begin{array}{c}-0.087^{* *} \\
(0.018) \\
\{-0.017\}\end{array}$ & $\begin{array}{l}0.031^{+} \\
(0.017) \\
\{0.119\}\end{array}$ \\
\hline Black & $\begin{array}{c}-0.273 \\
(0.389) \\
\{-0.076\}\end{array}$ & $\begin{array}{c}0.437 \\
(0.277) \\
\{0.097\}\end{array}$ & $\begin{array}{c}-0.932^{*} \\
(0.437) \\
\{-0.195\}\end{array}$ & $\begin{array}{c}0.613^{*} \\
(0.289) \\
\{0.186\}\end{array}$ \\
\hline Hispanic & $\begin{array}{c}0.322 \\
(0.464) \\
\{0.024\}\end{array}$ & $\begin{array}{c}0.592 \\
(0.382) \\
\{0.090\}\end{array}$ & $\begin{array}{c}0.755 \\
(0.616) \\
\{0.091\}\end{array}$ & $\begin{array}{c}0.566 \\
(0.489) \\
\{0.070\}\end{array}$ \\
\hline High School Graduate & $\begin{array}{l}-0.037 \\
(0.294) \\
\{0.052\}\end{array}$ & $\begin{array}{l}-1.003^{* *} \\
(0.238) \\
\{-0.183\}\end{array}$ & $\begin{array}{c}0.063 \\
(0.346) \\
\{0.066\}\end{array}$ & $\begin{array}{c}-0.878^{*} \\
(0.264) \\
\{-0.187\}\end{array}$ \\
\hline Some College & $\begin{array}{c}0.039 \\
(0.374) \\
\{-0.030\}\end{array}$ & $\begin{array}{c}0.625^{+} \\
(0.321) \\
\{0.113\}\end{array}$ & $\begin{array}{c}0.376 \\
(0.413) \\
\{0.054\}\end{array}$ & $\begin{array}{c}0.143 \\
(0.365) \\
\{0.006\}\end{array}$ \\
\hline
\end{tabular}




\begin{tabular}{|c|c|c|c|c|}
\hline College Graduate & $\begin{array}{c}0.392 \\
(0.379) \\
\{0.098\}\end{array}$ & $\begin{array}{c}-0.442 \\
(0.430) \\
\{-0.105\}\end{array}$ & $\begin{array}{c}1.052^{*} \\
(0.486) \\
\{0.185\}\end{array}$ & $\begin{array}{c}-0.134 \\
(0.508) \\
\{-0.094\}\end{array}$ \\
\hline \multicolumn{5}{|l|}{$\begin{array}{l}\text { Employer } \\
\text { Characteristics }^{a}\end{array}$} \\
\hline Employer Size & $\begin{array}{c}-0.500^{* *} \\
(0.055) \\
\{-0.092\}\end{array}$ & $\begin{array}{c}0.004 \\
(0.052) \\
\{0.030\}\end{array}$ & $\begin{array}{c}-0.329^{* *} \\
(0.060) \\
\{-0.057\}\end{array}$ & $\begin{array}{c}0.034 \\
(0.055) \\
\{0.028\}\end{array}$ \\
\hline Union Status & $\begin{array}{c}-0.311 \\
(0.352) \\
\{-0.072\}\end{array}$ & $\begin{array}{c}0.256 \\
(0.243) \\
\{0.066\}\end{array}$ & $\begin{array}{c}-1.376^{* *} \\
(0.509) \\
\{-0.193\}\end{array}$ & $\begin{array}{c}-0.612^{*} \\
(0.302) \\
\{-0.040\}\end{array}$ \\
\hline \multicolumn{5}{|l|}{ Job Characteristics } \\
\hline Physically Demanding & $\begin{array}{c}0.121 \\
(0.284) \\
\{0.020\}\end{array}$ & $\begin{array}{c}0.037 \\
(0.248) \\
\{-0.000\}\end{array}$ & $\begin{array}{c}-0.135 \\
(0.299) \\
\{-0.023\}\end{array}$ & $\begin{array}{c}0.016 \\
(0.267) \\
\{0.012\}\end{array}$ \\
\hline Pace Set By Others & $\begin{array}{c}0.350 \\
(0.259) \\
\{0.067\}\end{array}$ & $\begin{array}{c}-0.047 \\
(0.219) \\
\{-0.030\}\end{array}$ & $\begin{array}{c}0.284 \\
(0.325) \\
\{0.049\}\end{array}$ & $\begin{array}{c}-0.014 \\
(0.260) \\
\{-0.021\}\end{array}$ \\
\hline Mentally Demanding & $\begin{array}{c}-0.814 \\
(0.539) \\
\{-0.155\}\end{array}$ & $\begin{array}{c}0.155 \\
(0.530) \\
\{0.077\}\end{array}$ & $\begin{array}{c}-0.021 \\
(0.587) \\
\{0.002\}\end{array}$ & $\begin{array}{c}-0.095 \\
(0.568) \\
\{-0.018\}\end{array}$ \\
\hline Deal with People & $\begin{array}{c}-0.278 \\
(0.283) \\
\{-0.052\}\end{array}$ & $\begin{array}{c}0.012 \\
(0.246) \\
\{0.019\}\end{array}$ & $\begin{array}{c}-0.005 \\
(0.391) \\
\{0.008\}\end{array}$ & $\begin{array}{c}-0.145 \\
(0.298) \\
\{-0.030\}\end{array}$ \\
\hline
\end{tabular}

Note: Reference category is individual remained with employer at onset. a Employer size and union status were missing for approximately 20 percent of the sample. Missing cases were replaced with mean values. Dummy variables indicating missing cases were not significant. Unreported regressors indicating the primary health condition at onset were included in the estimation to account for differences in the types of impairments. $+\mathrm{p}<.10 ;{ }^{*} \mathrm{p}<.05 ;{ }^{* *} \mathrm{p}<.01$. 
Table 4. Post-Impairment Changes in Job Demands, By Employment Response and Gender

\begin{tabular}{|c|c|c|c|c|c|c|c|}
\hline \multicolumn{8}{|c|}{ Men } \\
\hline \multirow[t]{2}{*}{ Job Characteristics } & \multicolumn{3}{|c|}{ Remained with Employer } & \multicolumn{3}{|c|}{ Changed Employers } & \multirow{2}{*}{$\begin{array}{l}\text { Changed - } \\
\text { Remained } \\
\text { Difference }\end{array}$} \\
\hline & Before & After & Difference & Before & After & Difference & \\
\hline & \multicolumn{3}{|c|}{$(N=345)$} & \multicolumn{3}{|c|}{$(\mathrm{N}=159)$} & \\
\hline Physical Effort & 65.2 & 50.2 & $15.0^{* *}$ & 69.0 & 50.1 & $18.9^{* *}$ & 3.9 \\
\hline Lift Heavy Loads & 43.8 & 30.3 & $13.5^{* *}$ & 49.1 & 31.6 & $17.5^{* *}$ & 4.0 \\
\hline Stoop, Kneel, Crouch & 52.9 & 41.1 & $11.8^{* *}$ & 56.0 & 38.9 & $17.1^{* *}$ & 5.3 \\
\hline Good Eyesight & 89.2 & 83.7 & $5.5^{* *}$ & 86.2 & 83.3 & $2.9^{+}$ & $-2.6^{+}$ \\
\hline Intense Concentration & 86.0 & 81.6 & $4.4^{+}$ & 83.5 & 82.5 & 1.0 & -3.4 \\
\hline Pace Set By Others & 61.7 & 54.2 & $7.5^{* *}$ & 68.2 & 61.1 & $7.1^{* *}$ & $-0.4^{+}$ \\
\hline Deal with People & 76.3 & 76.0 & 0.3 & 73.7 & 77.6 & -3.9 & -4.2 \\
\hline
\end{tabular}




\begin{tabular}{|c|c|c|c|c|c|c|c|}
\hline \multirow{3}{*}{ Job Characteristics } & \multicolumn{6}{|c|}{ Women } & \multirow{3}{*}{$\begin{array}{l}\text { Changed } \\
\text { Remained }\end{array}$} \\
\hline & \multicolumn{3}{|c|}{ Remained with Employer } & \multicolumn{3}{|c|}{ Changed Employers } & \\
\hline & Before & After & Difference & Before & After & Difference & \\
\hline & \multicolumn{3}{|c|}{$(\mathrm{N}=241)$} & \multicolumn{3}{|c|}{$(\mathrm{N}=103)$} & \\
\hline Physical Effort & 62.5 & 53.8 & $8.7^{* *}$ & 56.2 & 34.2 & $22.0^{* *}$ & $13.3^{* *}$ \\
\hline Lift Heavy Loads & 37.5 & 26.0 & $11.5^{* *}$ & 33.9 & 22.0 & $11.9^{* *}$ & $0.4^{+}$ \\
\hline Stoop, Kneel, Crouch & 47.4 & 38.2 & $9.2^{* *}$ & 44.1 & 22.7 & $21.4^{* *}$ & $12.2^{* *}$ \\
\hline Good Eyesight & 91.7 & 91.3 & 0.4 & 88.8 & 85.0 & $3.8^{+}$ & 3.4 \\
\hline Intense Concentration & 85.8 & 84.7 & 1.1 & 86.3 & 83.7 & 2.6 & 1.5 \\
\hline Pace Set By Others & 69.7 & 63.1 & $6.6^{* *}$ & 71.6 & 61.0 & $10.6^{* *}$ & $4.0^{+}$ \\
\hline Deal with People & 81.0 & 78.5 & 2.5 & 84.3 & 84.3 & 0.0 & -2.5 \\
\hline
\end{tabular}

$+\mathrm{p}<.10 ;{ }^{*} \mathrm{p}<.05 ;{ }^{* *} \mathrm{p}<.01 ;{ }^{* * *} \mathrm{p}<.001$ 
Table 5. Employer Accommodation Following the Onset of a Health Impairment, By Employment Response and Gender

\begin{tabular}{|c|c|c|c|c|c|c|}
\hline & \multicolumn{3}{|c|}{ Men } & \multicolumn{3}{|c|}{ Women } \\
\hline & $\begin{array}{c}\text { Remained } \\
\text { with Employer } \\
(\mathrm{N}=345)\end{array}$ & $\begin{array}{c}\text { Changed } \\
\text { Employers } \\
(\mathrm{N}=159)\end{array}$ & $\begin{array}{l}\text { Changed - } \\
\text { Remained }\end{array}$ & $\begin{array}{c}\text { Remained with } \\
\text { Employer } \\
(\mathrm{N}=241)\end{array}$ & $\begin{array}{c}\text { Changed } \\
\text { Employers } \\
(\mathrm{N}=103)\end{array}$ & $\begin{array}{l}\text { Changed - } \\
\text { Remained }\end{array}$ \\
\hline Accommodated & & & Difference & & & Difference \\
\hline Number & 107 & 21 & & 90 & 24 & \\
\hline Percent & 29.2 & 14.1 & $-15.1^{* * *}$ & 36.9 & 24.9 & $-12.0^{+}$ \\
\hline \multicolumn{7}{|l|}{$\begin{array}{l}\text { Detailed Types of } \\
\text { Accommodation }\end{array}$} \\
\hline & $\%$ & $\%$ & Difference & $\%$ & $\%$ & Difference \\
\hline Someone to Help & 11.1 & 4.5 & -6.6 & 13.6 & 6.4 & -7.2 \\
\hline Shorter Work Day & 8.9 & 3.7 & -5.2 & 11.4 & 7.7 & -3.7 \\
\hline Change Schedule & 8.9 & 6.7 & -2.2 & 12.6 & 5.8 & -6.8 \\
\hline More Breaks & 11.3 & 5.9 & -5.4 & 12.8 & 5.8 & -7.0 \\
\hline $\begin{array}{l}\text { Special } \\
\text { Transportation }\end{array}$ & 1.5 & 1.2 & -0.3 & 1.1 & 0.0 & -1.1 \\
\hline $\begin{array}{l}\text { Different Job } \\
\text { Duties }\end{array}$ & 15.0 & 5.5 & -9.5 & 16.4 & 7.7 & -8.7 \\
\hline $\begin{array}{l}\text { Training, New } \\
\text { Skills }\end{array}$ & 2.7 & 4.9 & $-2.2^{* *}$ & 5.3 & 7.7 & 2.4 \\
\hline Special Equipment & 5.3 & 2.9 & $-2.4^{+}$ & 4.3 & 1.9 & -2.4 \\
\hline
\end{tabular}

$+\mathrm{p}<.10 ;{ }^{*} \mathrm{p}<.05 ;{ }^{* *} \mathrm{p}<.01 ;{ }^{* * *} \mathrm{p}<.001$ 